\title{
Real-World Flowcharting - Willy Wonka Style!
}

Kelly Noe, Stephen F. Austin State University, USA

\begin{abstract}
The purpose of this paper is to discuss the development, implementation and outcome of a fieldbased learning flow-charting project that was conducted in an accounting information systems (AIS) course. The emphasis for the project was strengthening the students' critical thinking skills. This paper advances AIS education by sharing a field-based learning project geared toward AIS.
\end{abstract}

Keywords: Critical Thinking Skills; Field-Based Learning; Cooperative Learning

\section{INTRODUCTION}

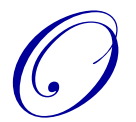

ften students are unable to complete an internship for various reasons. These students miss out on the opportunity to experience the "real-world." The author had the opportunity to conduct a field-based learning project in an accounting information systems course. This enabled students to experience the real-world without having to leave the area or give up current employment for an internship that may only exist for a partial semester. The purpose of this paper is to discuss the development, implementation and outcome of a fieldbased learning flow-charting project that was conducted in the accounting information systems course.

College students must have critical thinking skills to have successful careers. The author found that the students often want to learn only what is on the exam and nothing more. The truth is, in many cases, that they really do not want to learn. As an instructor, the author jokes, telling them that they want the instructor to tell them the tree is green and then come back to class for an exam and tell the instructor the tree is green and call it learning. The author wants students to understand that in the professional world, there will not be clearly defined problems with known solutions.

\section{EXISTING LITERATURE}

Tan et al. (2013) discuss how students must complete more complex tasks than just listening to lecture and working homework problems in order to learn and apply the material. It is the job of the educator to ensure that students actually learn the material and do not just memorize it for the exam and then do a "memory dump" after the exam. In 1987 the National Council for Excellence in Critical Thinking defined critical thinking as "the intellectually disciplined process of actively and skillfully conceptualizing, applying, analyzing, synthesizing, and/or evaluating information gathered from, or generated by, observation, experience, reflection, reasoning, or communication, as a guide to belief and action" (Scriven and Paul 1987). Hwang et al. (2005) discuss that the Accounting Education Change Commission is pushing for educators to move away from the traditional lecture and adapt the cooperative learning approach in order to prepare accounting graduates who are capable of identifying, analyzing, interpreting and exercising judgment on the reliability and relevancy of accounting information. When students enter the profession, they will be expected to interact and work with other employees. Cooperative learning also helps develop this skill. It is imperative that students understand that there are not clearly defined problems in the real-world with a solutions manual for their coworkers or boss to consult in order to determine if they answered the question correctly. In the real-world, the students must be able to look at the situation, determine the problem, solve the problem and then assess if their solution was appropriate. This type of problem solving mandates that students possess critical thinking skills. 
PricewaterhouseCoopers points out that at the university level too much emphasis is placed on "the right answer" and that students will benefit from opportunities to develop the insight and confidence to help them identify and solve real-world problems ( $\mathrm{PwC} 2003)$.

\section{DEVELOPMENT OF THE PROJECT}

The author had the opportunity to answer this call to expose students to the real-world. The University offers a program that consists of faculty learning communities. Within this community we work with the Office of High Impact Learning to develop projects that develop students' critical thinking skills. The project that was conducted Accounting Information Systems (AIS) course participated in was a field-based learning project. The author spent one semester developing the project and then implemented the project during the next semester. At the beginning it was hard to even think of an idea of how to take AIS students into the real-world. The class consisted of 30 students which presented additional logistic problems. The AIS course is a senior-level course that is required of all accounting students in the bachelor and masters program. For many students this course is taken in their final semester if they are only seeking a four year degree.

The author learned that the local candy manufacturer would be purchasing a new software system and would be open to the students working with the accountants at the manufacturer. One of the issues with implementing field-based learning is moving away from the traditional learning environment. As an instructor, it can be unnerving to send students into the real world and for the students, it is uncomfortable. In the fall of 2012, the author worked with the Controller of the candy manufacturer to develop a project that would be beneficial to her and the students. In addition to the Controller, the factory employs eight accountants. The Controller planned to purchase a new software system for the company. In order to obtain bids for the new software system, she needed detail of the workflow for each accountant. The Controller and the author decided that the students would flowchart the job of each accountant. A tour was set up for the students at the beginning of the project and then they were able to meet in groups with the accountants. The students were divided into eight groups - one for each accountant.

Following are the eight departments the student groups worked with:

- Orders / Customer Service - (reviews incoming orders and communicates with brokers/customers any issues with the purchase order.)

- $\quad$ Order Entry - (enters sales orders into accounting system, releases orders to warehouse floor for pulling order, and invoices orders after warehouse staff has pulled for shipping)

- $\quad \mathrm{MDF} /$ Credits/Rebates - (receives requests for credits and allowances from broker/customers, verifies qualifications are met, and processes for payment/credit)

- Accounts Receivable - (verifies customer account status prior to release of order, posts payments and credits, and works past due accounts)

- $\quad$ Logistics - (freight quotes, verifies order counts prior to shipping)

- $\quad$ Accounts Payable - (purchase order receipt to invoice, vendor insurance, w-9, payments)

- $\quad$ Payroll - (time entry, deductions, tax rate schedules, $401 \mathrm{k}$ deferrals and loans, check/direct deposit)

- Assistant Controller - (maintain inventory accounting, commissions, logistics invoice reconciliation, ACH payments)

The AIS course can be viewed as a course where all of the accounting material the students have learned comes together. The author uses the Systems Understanding Aid in the course to demonstrate that when the student enters the profession they will not be given a list of 1,2, and 3 to do. In addition the accounting information is not segregated. In typical intermediate courses the students learn accounting topics in separate chapters, such as a chapter on accounts payable and a chapter on accounts receivable. The AIS course helps bring all of the separate topics together so that students get the "big picture" of the financial statements. Having the exposure to the accounting information system of an actual business really emphasized the "big picture" for the students. Also, it helped them understand that there really is not a "right" answer to a problem. There are only educated solutions that have to be implemented and monitored. 
At the beginning of the spring 2013 semester the author explained the project to the students. The project was started about 8 weeks into the semester. The author had to have time in a traditional setting to give the students the tools they would need to successfully execute the project. When the project was explained, the students were not comfortable with the idea. It was interesting to see how their concern increased when they learned their work would be given back to the Controller for use in gathering bids for the new software system. The students felt like they had to raise the bar because their work was going to be seen and used by someone beyond their professor.

The class, as a whole, wanted detailed, specific directions. They were anxious when they learned that the author did not have final answers and did not know the job of the accountants. The author liked the idea of not having clearly defined answers to the project which forced the students to work hard and utilize their critical thinking skills. What was found was the more they were pushed, the farther they went. When teaching flowcharting, the author always explains that no two flowcharts are the same; two people can be given the same information and develop significantly different flowcharts with both being correct. There is nothing that compares to the students learning this first-hand.

\section{IMPLEMENTATION OF THE PROJECT}

With funding from a grant through the Office of High Impact Learning, the author was able to hold a kickoff lunch at a local restaurant before the class toured the factory. The idea behind the lunch was to get the students gathered in a timely manner and have them accounted for before the tour was to begin. This was successful. The author assumes the lunch was enticing enough to get the students to come. As expected a few students were late, but this just meant they had to eat faster and everyone was on time for the tour.

The students were allowed the students to self-select into their groups. This allowed students that live close, have similar schedules, are already comfortable with each other and any other reason students would prefer to work in a certain group to choose each other as group members. This concept followed the recommendation of Connerley and Mael (2001) and provided basic information to the students and allowed the students to self-select into groups based on attributes each student determined were important as a result of the basic information.

After the tour the students met in their group with the group's assigned accountant. The project was structured so that the students had about 6 weeks out of class to meet with the accountants, work on the project and meet with me when they needed help. This gave the students the freedom to schedule meetings during class time rather than trying to meet outside of class. Only one member of the group had to be present as a group representative. The business was only open from $8 \mathrm{am}$ to $5 \mathrm{pm}$ during the week; this requirement made it easier for students to schedule the meetings during work hours.

\section{OUTCOMES OF THE PROJECT}

The author was impressed with how well the students handled the responsibility. In many cases they chose one main job of the accountant and made that the focus of the flowchart. Most of the students found that once they began the project it was much more "doable" than they first believed.

Each group turned in a flowchart and $50 \%$ of their final grade consisted of the flowchart grade. A written was required to be sent in by each group every week or so to ensure that the students were not neglecting the project. Further, with each written report the author advised them to document any problems that might arise within the group. The author did not want to get to the end of the project only to find out the group had a problem that would make it difficult to fairly assign the grades. The groups did very well with this process. There were a few minor problems that were all easily addressed.

In addition to the written reports that counted as part of the grade, there was also a required a rough draft of the flowchart from each group. This seemed to put the students at ease, knowing that if they completely misunderstood the project, that they could have a second chance. The groups each then turned in a final flowchart and documentation describing the flowchart. An example of the documentation can be found in the Appendix. The accompanying flowchart can be requested from the author as it was too large to fit in the paper. The documentation 
presented was created by Rebecca Boney, Christina Milburn and Cadie Weaver. The author must give them credit for all of the work presented in the Appendix.

\section{PROFESSOR STANDPOINT}

A field-based learning project forces the professor to form community relationships, move out of the traditional classroom and requires a lot of planning ahead. There is no "staying one chapter ahead of the students" with a project like this. It was a risky venture but in this case it was successful. The author knew most of the students in the class because the author had worked with them with Beta Alpha Psi or had taught them in other courses before they took the AIS course. Consulting with the groups and coordinating with the factory were both time consuming. However, the payoff from the author's standpoint was that the students had a positive experience in the end and actually learned and applied critical thinking skills.

Future students will benefit from this project as well. The author intends to use the information as case studies to allow future students to flowchart from the written documentation of the students who actually gathered the information. The author will then have future AIS classes put the entire process together, linking the documents from one accountant to the next.

\section{FEEDBACK FROM THE ENTITY}

All of the information gathered by the students was provided to the candy manufacturer. To date, no feedback to document has been received from the company. The author plans to follow-up with the Controller to learn if a system was purchased and if the student work was useful. The author does intend to continue the relationship with the firm and develop additional field-based learning projects.

\section{CONCLUSION}

Field-based learning is true learning for the students. Critical thinking skills need to be used and encouraged by any learning system. The students involved in this project participated in cooperative learning, fieldbased learning and dealt with an ambiguous problem that did not have an end solution in place. While it pushed both the students and professor out of the comfort zone of traditional learning, it was an overall positive experience for both parties. Future AIS students will benefit from the work of the current students by having access to the knowledge already gained and being able to extend the flowcharts.

\section{AUTHOR INFORMATION}

Kelly Noe, PhD, CPA, CGMA is an Assistant Professor with the Gerald W. Schlief School of Accountancy at Stephen F. Austin State University, P.O. Box 13005, SFA Station, Nacogdoches, TX 75962 USA. Her research areas in include non-profit accounting concentrated in the healthcare industry, accounting information systems and financial accounting. She teaches in the areas of Accounting Information Systems, Intermediate Accounting and Graduate Accounting Research. E-mail: noekelly@sfasu.edu.

\section{REFERENCES}

Connerley, M. L., and F. A. Mael. 2001. The importance and invasiveness of student team selection criteria. Journal of Management Education 25(5): 471-493

Hwang, R., G. Lui, and M. Tong. 2005. An empirical test of cooperative learning in a passive learning environment. Issues in Accounting Education 20 (2): 151-165

PricewaterhouseCoopers (PwC). 2003. Education for the Public Trust: The PricewaterhouseCoopers Position on Accounting Education. New York, NY: PwC

Scriven, M., and R. Paul. 1987. Critical Thinking as Defined by the National Council for Excellence in Critical Thinking. Statement presented at the 8th Annual International Conference on Critical Thinking and Education Reform, Summer, 1987

Tan, J., D.C. Satin and C.W.K Lubwama. 2013. A Real-World Business Approach to Teaching M.B.A Managerial Accounting: Motivation, Design, and Implementation. American Accounting Association 28(3):375-402 


\title{
APPENDIX
}

\author{
Atkinson Candy Company Payroll Process
}

There are two people involved in the payroll process; Mark Love (plant manager), and Angie Butler (payroll accountant).

1. On Monday morning Mark prints the time clock information so that he can verify the hours worked for employees and fix any mistakes.

2. Mark sends Angie the corrected information for her to double check and she sends back the final copy to him.

3. Angie prints payroll data entry (all deductions are automatically calculated by the computer system). She manually calculates any one time deductions, refunds, or adjustments.

4. Angie prints the deduction register that contains all deductions and what employee they are for.

5. Angie checks deduction totals and double checks them against her spreadsheet where she calculated them.

6. Angie prints the employer's expense summary that contains the total withholdings.

7. Andin prints the checks:

A. Checks for employees in the office are directly deposited.

B. Plant workers receive a physical check.

8. Angie stamps every check with the president's signature.

9. The department supervisors are given the checks to pass out to employees.

10. Angie prints the check register that contains check numbers, employee name and number, withholdings, deductions, the number of physical checks, and the number of direct deposit.

11. Angie prints the direct deposit register that contains direct deposit numbers, employee name and number, withholdings, deductions, and number of direct deposit.

12. Angie logs into the bank website and enters all direct deposit amounts and to which employee, and then prints the bank confirmation.

13. Angie prints the daily transaction register.
A.
All journal entries are automatically posted to the general ledger. 
Extra Information About Payroll

1. Two different payrolls are maintained:

A. Weekly: Thursday payday for factory and office workers.

B. Semimonthly: The $1^{\text {st }}$ and the $15^{\text {th }}$ for executives.

3. They have a calendar that shows the days that they are off.

4. 12 departments:
A. Office
B. President
C. Maintenance
D. Shipping
E. Supervisors -2 per department
F. Kitchen $1^{\text {st }}$ shift
G. Kitchen $2^{\text {nd }}$ shift
H. Wrapping room $1^{\text {st }}$ shift
I. Wrapping room $2^{\text {nd }}$ shift
J. Batch rollers $1^{\text {st }}$ shift
K. Batch rollers $2^{\text {nd }}$ shift

5. $401 \mathrm{~K}$ money can be borrowed if needed and are listed as a one-time deduction on the deduction register. 